\title{
Cassava Root Necrosis Disease (CRND): A New Crop Disease Spreading in Western Democratic Republic of Congo and in Some Central African Countries
}

\author{
Bakelana Zeyimo ${ }^{1,3,4}$, Justin Pita ${ }^{3}$, Monde Godefroid ${ }^{3,4}$, Mahungu Nzola ${ }^{2}$, Lema Munseki ${ }^{4}$, Tshilenge Kanana ${ }^{4}$ \\ \& Kalonji Mbuyi ${ }^{4}$ \\ ${ }^{1}$ National Institute for Agricultural Research Studies (INERA), Democratic Republic of Congo \\ ${ }^{2}$ International Institute of Tropical Agriculture (IITA), Democratic Republic of Congo \\ ${ }^{3}$ West African Virus Epidemiology (WAVE), Abidjan, Ivory Coast \\ ${ }^{4}$ Agriculture Faculty, Kinshasa University, Democratic Republic of Congo \\ Correspondence: Bakelana Zeyimo, National Institute for Agricultural Research Studies (INERA), Democratic \\ Republic of Congo. Tel: 243-81-190-8783. E-mail: bakelanatony@hotmail.com
}

$\begin{array}{ll}\text { Received: November 27, } 2019 & \text { Accepted: January 2, } 2020 \quad \text { Online Published: February 15, } 2020 \\ \text { doi:10.5539/jas.v12n3p105 } & \text { URL: https://doi.org/10.5539/jas.v12n3p105 }\end{array}$

This research is financed by the WAVE/BMGF program.

\begin{abstract}
Cassava is consumed in the Democratic Republic of Congo (DRC) as a staple food for the majority of the Congolese population. This crop is used in several forms: as fufu, chikwangue and pondu; cassava leaves are the most consumed vegetable in the country.

In 2002, cassava root symptoms similar to cassava brown streak disease (CBSD) were reported for the first time in western DRC. PCR assays, using primers specific to Cassava brown streak virus (CBSV), failed to detect or identify any viral pathogens in diseased cassava samples from western DRC. Therefore, next generation sequencing (NGS) techniques were used as they are able to sequence full organism genomes and are widely used for the identification of pathogens responsible for new diseases. The main objective of this study was to identify the pathogens causing root necrosis in western DRC.

Whatman ${ }^{\circledR} \mathrm{FTA}^{\mathrm{TM}}$ cards were used to collect 12 cassava leaf samples from plants with symptoms indicative of very severe root necrosis, as well as two asymptomatic samples. These 12 samples were sent to Australia at the University of Western Australia in Perth for next generation sequencing (NGS) using the Illumina HiSeq platform.

Additional bioinformatics tools included Geneious, CLC workbench, ParaKraken and Kaijou software for short DNA sequences. No viruses (including CBSV) were found in any of the DRC samples. These preliminary results confirm all the previous negative results obtained using PCR and CBSV primers. However, NGS analyses did reveal the presence of a number of bacterial and fungal taxa. These will require further investigation and tests such as the Koch Postulates, to establish their specific pathogenic role in cassava.

This is the first scientific evidence that no currently known virus is responsible for the disease which had been referred to previously as 'CBSD-like disease'. Consequently, the disease found in DRC cassava samples has been designated 'Cassava Root Necrosis Disease' or CRND.
\end{abstract}

Keywords: NGS, PCR, Illumina HiSeq, CBSD-like, CRND

\section{Introduction}

Cassava (Manihot esculenta Crantz, family Euphorbiaceae) produces carbohydrate-rich storage roots, which are a staple food crop for approximately 800 million people worldwide (Food and Agriculture Organization, 2013). In Africa, cassava is the second most important food staple in terms of per capita calories consumed (Nweke, 2004). 
Cassava (Manihot esculenta) production is important to the economy of the Democratic Republic of Congo (DRC). It is one of the country's principal crops, with per capita consumption of $353 \mathrm{~kg}$ per year, which is the highest in the world (Mbago \& Lotombe, 2017). Zaire, now DRC, was the world's largest consumer of cassava with Republic of Congo ranked second in 1996 (Dufour et al., 1996).

Storage roots are used as a fresh source of carbohydrates and the flour derived from the processed roots is consumed as an everyday-food, sold in local markets or used in several industrial food products (Hillocks \& Thresh, 2002). Recent research has suggested that, in comparison to other staple food crops, cassava may be highly resilient to climate change and could provide food security opportunities for Africa (Jarvis et al., 2012).

Cassava production of in East and Central Africa is severely constrained by two viral diseases, cassava mosaic disease (CMD) and cassava brown streak disease (CBSD). Together, it is estimated that these diseases cause annual losses of US\$1 billion (IITA, 2014b) and adversely affect food security in the region (Patil et al., 2015). In 2004, CBSD, which had been thought to be confined to coastal lowlands, was found at altitudes above $1000 \mathrm{~m}$ above sea level (Alicai et al., 2007). Infections of cassava plants showing CBSD symptoms at higher altitudes in Uganda were confirmed by RT-PCR (Alicai et al., 2007). There have since been additional CBSD reports from Burundi (Bigirimana et al., 2011), Rwanda (FAO, 2011), eastern DRC (Mulimbi et al., 2012), South Sudan (Alicai et al., 2017) and Mayotte Island (Roux-Cuvelier et al., 2014).

CBSD is caused by a single-stranded RNA virus, family Potyviridae; genus Ipomovirus (Mongeret al., 2001a). Two genetically-distinct strains of CBSV were recognized in East Africa (Mbanzibwa et al., 2009). These were shown to be two distinct species, namely Cassava brown streak virus (CBSV) and Ugandan cassava brown streak virus (UCBSV) (Monger et al., 2010).

Both CBSV and UCBSV are transmitted by the whitefly species complex Bemisia tabaci Gennadius in the field (Mware et al, 2019) and through the propagation of infected cuttings used for planting. CBSD was known to be endemic in coastal East Africa and in parts of Malawi until recently when outbreaks were reported in Uganda, western Tanzania and Kenya. Other countries where CBSD has been reported include Mozambique, Rwanda, Burundi and in isolated parts of the DRC (Ndunguru et al., 2015). The strains of Cassava brown streak virus cause economic losses of up to $\$ 100$ million USD annually (Ndunguru et al., 2015).

In the early 2000s, cassava root necrosis (Figure 1) similar to that caused by CBSD was first reported in the western provinces of DRC (Kinshasa and Kongo Central) by Mahungu et al. (2003).To date, diagnosis through PCR has been unsuccessful in detecting any known potential causal agent for the observed symptoms. Thus, up to now, the disease has been referred to as 'CBSD-like disease' (Bakelana et al., 2019a).

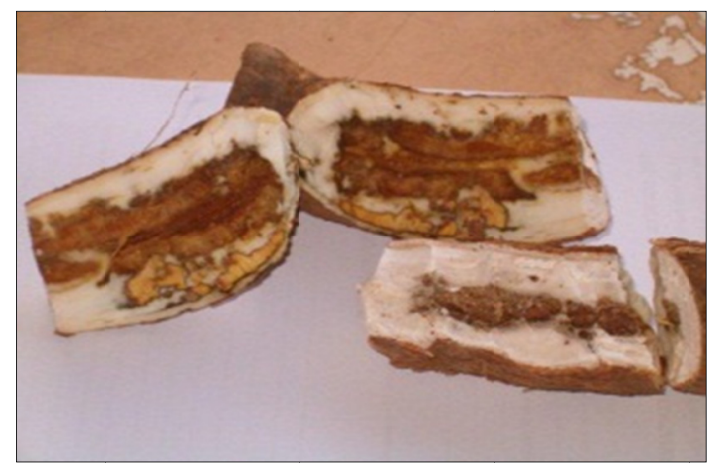

Figure 1. Typical root necrosis of CRND observed in western DRC

In November 2018, in Kinshasa during the drafting meeting of the DRC cassava viral disease response plan, one of the recommendations was that the term 'CBSD-like' should no longer be used, but that the term Cassava Root Necrosis Disease (CRND) should be used instead.

This recommendation was also reminded during the scientific day on diseases and pests of cultivated plants in DRC. This scientific day was organized on August 3rd by the Plant Clinic of Kinshasa.

This name change was based on the results of NGS analysis undertaken in this study. This analysis did not find evidence of any virus (including known CBSD viruses) in our symptomatic cassava samples. 
Several attempts have been undertaken since 2004 to identify the causative agent for CRND in western DRC, using cassava leaf samples (including those from plants showing very severe symptoms)with no success to date (Bakelana et al., 2019a).

Molecular diagnosis results from five different laboratories, using PCR primers specific for the two known CBSVs (CBSV and UCBSV), produced negative results. This suggested that the causal agent of the CBSD-like disease in western DR Congo might be different from those known at present (Bakelana et al., 2019a). Conventional molecular methods have their limitations - as indicated by Adams et al. (2009) who indicated that real-time PCR may be too specific or not broad enough to successfully detect all the known variability within virus species and thus resulting in false negatives. With the advent of next generation, high-throughput, sequencing platforms (NGS), the metagenomic sequencing of diseased cassava plants to identify plant viruses has now become a widely-used method (Adams et al., 2009; Kreuze et al., 2019).

Despite the absence of typical CBSD foliar and stem symptoms and a failure of existing test methods to identify potential causal viral agents in diseased plants in western DRC, the project considered that it was still likely that CBSD viruses were spreading from East to Central Africa and causing this disease. It seemed feasible that other strains of CBSD - unidentified to date - might be responsible for these disease symptoms. Therefore, the aim of this study was to search for the causal agent using a broad diagnostic tool—that is, one not designed against specific or known targets.

In this paper, we report the first use of next generation sequencing to analyze the symptomatic cassava leaf samples from DRC. Based on the NGS results, we also propose that non-viral causal agents may be responsible for the symptoms exhibited in our cassava plant samples. Consequently, we are using the name 'Cassava root necrosis disease' and its acronym 'CRND' within this manuscript to refer to this disease.

\section{Materials and Methods}

\subsection{Field Sample Collection for NGS Analysis}

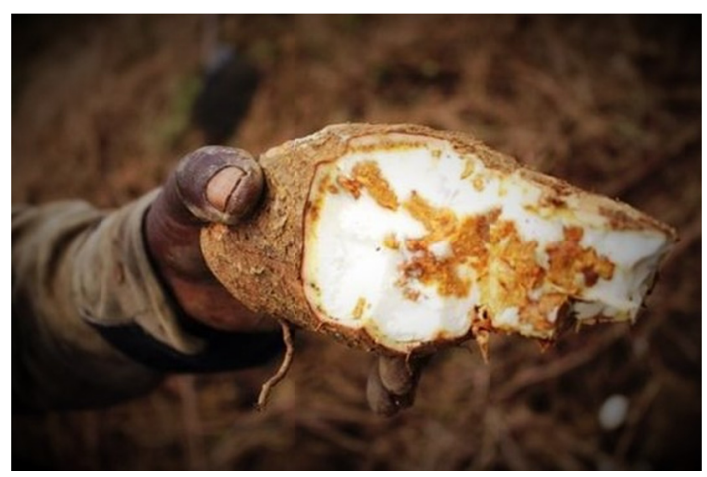

Figure 2. Cassava root of plants used for leaf sampling on FTA ${ }^{\mathrm{TM}}$ cards

Cassava fields (with plants more than 16 months old) in the 2 localities considered hotspots (ref) in western DRC were surveyed. Leaf material from plant with root necrosis was collected (Figures 2) on FTA ${ }^{\mathrm{TM}}$ cards.

A total of 12 leaf samples (Table 1) were collected from plants. They were crushed onto FTA ${ }^{\mathrm{TM}}$ cards according to the manufacturers' protocol in order to extract their DNA.

Cassava leaf samples were collected at Mvuazi research center and Lukuakua village on 29 and 30 November 2016.

Leaves samples were sampled according to Rwegasira et al. (2011) who found that the most suitable tissue samples for CBSV-detection were young tender leaves, youngest symptomatic leaves and the non-necrotic storage root tissue. The CBSD viruses were not detected from root necrotic tissues. 


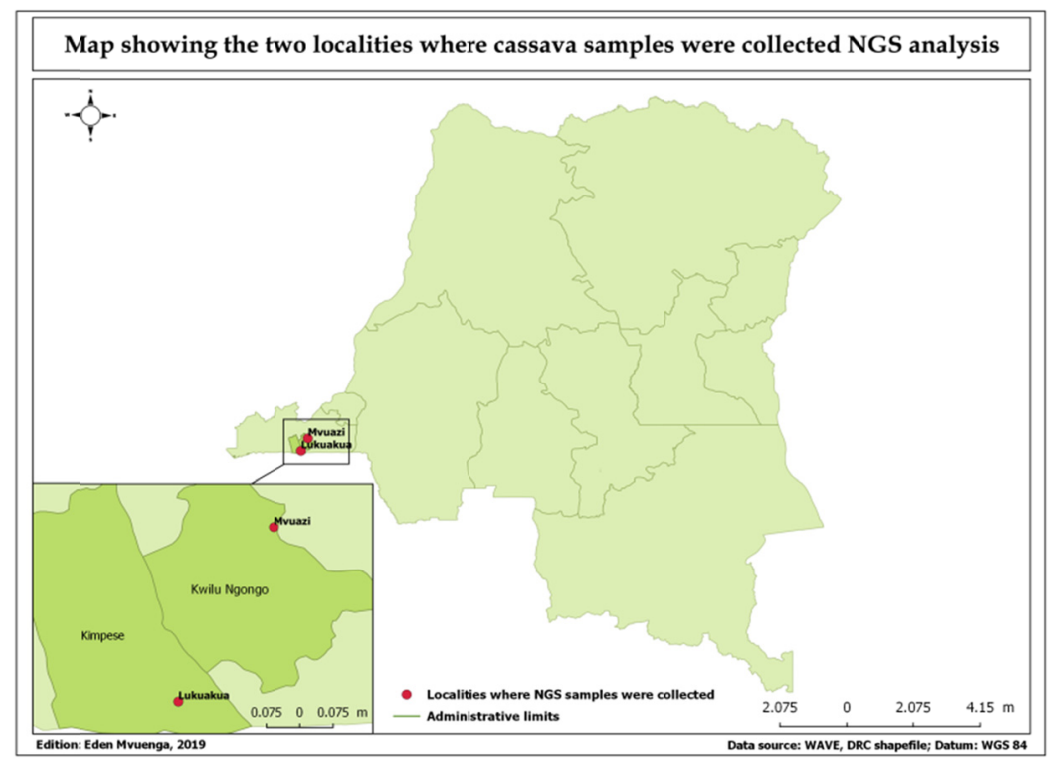

Figure 3. Hotspot disease locations where samples were collected

Table 1. Leaf samples details

\begin{tabular}{llll}
\hline Sample ID & Genotype & Location & Status \\
\hline 1 & Mputa & Mvuazi & Diseased plants \\
2 & Mputa & Mvuazi & Diseased plants \\
3 & Mputa & Mvuazi & Diseased plants \\
4 & Mputa & Mvuazi & Diseased plants \\
5 & Mputa & Mvuazi & Diseased plants \\
6 & Mvuazi & Lukuakua & Diseased plants \\
7 & Mvuazi & Lukuakua & Diseased plants \\
8 & RAV & Lukuakua & Diseased plants \\
9 & RAV & Lukuakua & Diseased plants \\
10 & Mputa & Lukuakua & Diseased plants \\
11 & RAV & Lukuakua & Apparently healthy plants \\
12 & TME 419 & Lukuakua & Apparently healthy plants \\
\hline
\end{tabular}

The $12 \mathrm{FTA}^{\mathrm{TM}}$ sample cards, previously labeled, were shipped to the University of Western Australia (UWA) in Perth to complete the DNA extraction and for subsequent NGS processing.

\subsection{Symptom Assessment}

A symptom severity score was then recorded for the root of each plant sampled, using the 1-to-5 scoring method described in Hillocks and Thresh (2000). Root necrosis severity was assessed as follows: $1=$ apparently healthy root; $2=$ less than $2 \%$ necrotic tissue; $3=2-5 \%$ necrotic tissue; $4=5-50 \%$ necrotic tissue; $5=$ more than $50 \%$ necrotic tissue.

\subsection{RNA Extraction (Ndunguru et al., 2015)}

RNA was extracted from approximately $100 \mathrm{mg}$ of cassava leaf using the CTAB (cetyltrimethyl ammonium bromide). The leaves were ground in a mortar containing $1 \mathrm{ml}$ extraction buffer $(2.0 \%$ (w/v) CTAB, $2.0 \mathrm{M} \mathrm{NaCl}$, $2.0 \%$ PVP, $0.5 \mathrm{M}$ EDTA, $1 \mathrm{M}$ Tris- $\mathrm{HCl}$ and $0.2 \% \beta$-mer-captoethanol (added immediately before use)). Then 750 $\mu \mathrm{l}$ of the extract was transferred into a $1.5 \mathrm{ml}$ micro-centrifuge tube and incubated at $65{ }^{\circ} \mathrm{C}$ for $15 \mathrm{~min}$ while shaking vigorously several times. The extract was then mixed with an equal volume (750 $\mu \mathrm{l})$ of chloroform: isoamyl alcohol (24:1); vortexed briefly and centrifuged (Hettich Centrifugen, D-78532, Germany) at 12,000 rpm for $10 \mathrm{~min}$ at $4{ }^{\circ} \mathrm{C}$. The top aqueous solution $(500 \mu \mathrm{l})$ was transferred into new micro-centrifuge tubes to which 0.6 vol $(300 \mu \mathrm{l})$ cold isopropanol was added. The content was then incubated at -20 for at least $10 \mathrm{~min}$ followed by centrifugation (Hettich Centrifugen, D-78532, Germany) at $13,000 \mathrm{rpm}$ for $10 \mathrm{~min}$ at $4{ }^{\circ} \mathrm{C}$ and the supernatant was discarded. 
The RNA pellet was then washed in $700 \mathrm{ml}$ of $70 \%$ ethanol and the tubes vortexed briefly before being incubated at $-20{ }^{\circ} \mathrm{C}$ for at least $10 \mathrm{~min}$. The tubes were then centrifuged for $5 \mathrm{~min}$ at 13,000 rpm. The ethanol was then removed and the pellet was air-dried. Finally the dried RNApellet were re-suspended in $100 \mu \mathrm{l}$ 1XTE/sterilized double distilled $\mathrm{H} 20$ on ice for about $30 \mathrm{~min}$ and stored at $-20^{\circ} \mathrm{C}$ before use.

\section{4 cDNA Library Preparation and Illumina Sequencing (Ndunguru et al., 2015)}

Total RNA extracts that presented 260/280 and 260/230 purity indices equal to or greater than 2.0 and integral RNA in electrophoresis and Bioanalyzer measurements (RIN > 8) were selected. The cDNA libraries were prepared from $1 \mu \mathrm{g}$ of total RNA using the IlluminaTruSeq Stranded Total RNA Sample Preparation kit with Ribo-Zero ${ }^{\mathrm{TM}}$ Plant according to the manufacturer's instructions (Illumina, San Diego, California). Briefly, after rRNA depletion and RNA fragmentation, first and second strand cDNA was synthesized, adapters were ligated to the 50 and 30 ends of the fragments and the fragments enriched by PCR. cDNA libraries final size and concentration of each library was estimated using a Bioanalyzer (Agilent, Santa Clara, CA, USA) and the Qubit (Invitrogen, Carlsbad, CA, USA), respectively. Ten nM library pools were prepared by mixing the libraries to achieve an equal molar concentration of each. Libraries were normalized, pooled and sequenced using a $2 \times 300$ cycle PE V3 Illumina kit. Paired end reads were generated using the Illumina MiSeq System at the Biosciences Eastern and Central Africa-International Livestock Research Institute (BECA-ILRI) Hub in Nairobi, Kenya.

\subsection{De Novo Sequence Assembly and Mapping (Ndunguru et al., 2015)}

For each sample, reads were first trimmed using CLC Genomics Workbench 6.5 (CLCGW) (CLC Bio) with the quality scores limit set to 0.01 , maximum number of ambiguities to two and removing any reads with $<30$ nucleotides (nt). Contigs were assembled using the de novo assembly function of CLCGW with automatic word size, automatic bubble size, minimum contig length 500, mismatch cost two, insertion cost three, deletion cost three, length fraction 0.5 and similarity fraction 0.9 . Contigs were sorted by length and the longest subjected to a BLAST search (blastn and blastx). In addition, reads were also imported into Geneious 6.1.6 (Biomatters) and provided with reference sequences obtained from Genbank.

\subsection{Library Preparation and Illumina Sequencing}

Total RNA and DNA extractions was carried out in the UWA from FTA samples and were sent to the Australian Genome Research Facility of the UWA for library preparation and sequencing on an Illumina HiSeq 2500.

\subsection{Sequences Analysis}

For each sample, reads were first trimmed using CLC Genomics Workbench 6.5 (CLCGW) (CLC Bio) with the following parameters: quality scores limit set to 0.01 , maximum number of ambiguities set to twoand removal of any reads with $<30$ nucleotides. Contigs were assembled using the de novo assembly function of CLCGW with automatic word size, automatic bubble size, minimum contig length 500, mismatch cost two, insertion cost three, deletion cost three, length fraction 0.5 and similarity fraction 0.9 . Contigs were sorted by length and the longest subjected to a BLAST search (blastn and blastx) (Altschul et al., 1990). In addition, reads were also imported into Geneious 6.1.6 (Drummond et al., 2010) (Biomatters) and provided with reference sequences obtained from Genbank (NC012698 for CBSV, GQ329864 for CBSV-T and NC014791 for UCBSV). These methods have been used previously for the successful recovery of whole CBSV and UCBSV genome sequences (Ndunguru et al., 2015; Alicai et al., 2016; Ateka et al., 2017).

Mapping was performed using Kaiju software with minimum overlap 10\%, minimum overlap identity $80 \%$, allow gaps $10 \%$ and fine tuning set to iterate up to 10 times.

While recent taxonomic classification programs achieve high speed by comparing genomic k-mers, they often lack sensitivity for overcoming evolutionary divergence; these results in large fractions of the metagenomic reads remaining unclassified. Kaiju is a novel metagenome classifier, which finds maximum (in-) exact matches on the protein level using the Burrows-Wheeler transform (Menzel et al., 2016).

It has been shown that that Kaiju classifies reads with higher sensitivity and similar precision compared with current k-mer-based classifiers, especially in genera that are under-represented in reference databases. It has also been demonstrated that Kaiju classifies up to 10 times more reads in real metagenomes. Kaiju can also process millions of reads per minute and can run on a standard PC (Menzel et al., 2016).

\section{Preliminary Results and Discussion}

After trimming and assembling NGS data outputs using CLC workbench and Geneious software, sequences were processed using the Kaiju and outputs are presented in Figures 4 and 5 below. The bioinformatic processes and 
analyses did not find evidence of any virus (including known CBSD viruses) in our symptomatic cassava samples. However, a number of bacterial and fungal taxa were recorded.

Samples 1-10, which were collected on diseased plants, presented fungi and bacteria while samples 11 and 12, which were collected on apparently asymptomatic plants presented only bacteria. No fungi were found in asymptomatic plants.

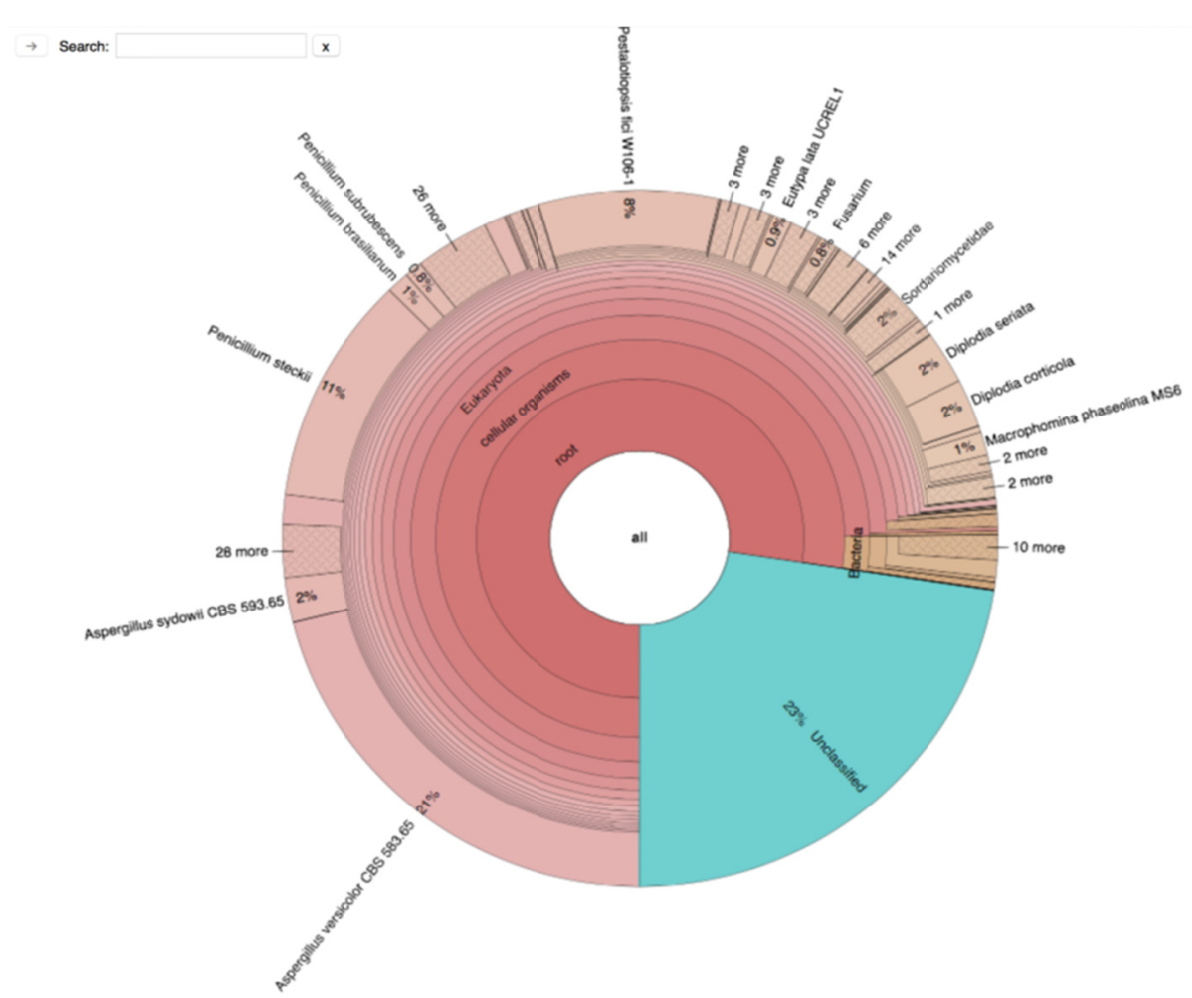

Figure 4. Example of a sample results showing list of microorganisms (bacteria and fungi) identified using Kaiju software

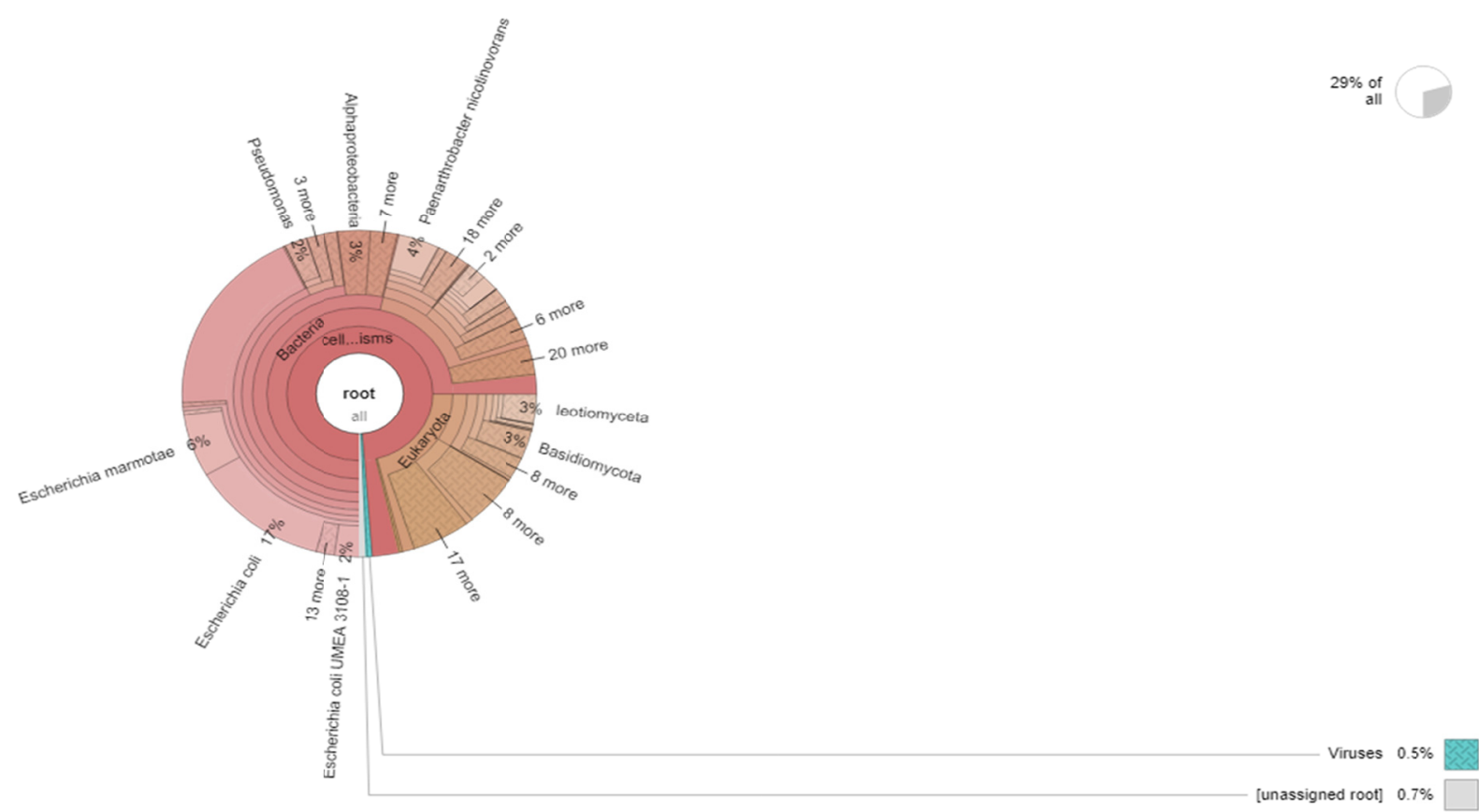

Figure 5. Lack of viruses in all tested samples (Kayju software) 
The figure 5 shows that viral sequences were quantified at $0.5 \%$.

The list of all microorganisms identified in all 12 samples and those suspected to play a pathogenic role in plant diseases according to the literature are presented in Tables 2 and 3 below.

Table 2. Bacteria and fungi identified through NGS in all 12 samples

\begin{tabular}{|c|c|}
\hline Microorganisms identified & Classification \\
\hline Acremonium chrysogenum & Fungus \\
\hline Aspergillus niger & Fungus \\
\hline Aspergillus sp. & Fungus \\
\hline Aspergillus sydowii & Fungus \\
\hline Aspergillus versicolor & Fungus \\
\hline Diaporthehelianthi & Fungus \\
\hline Diaportheampelina & Fungus \\
\hline Diaporthehelianthi & Fungus \\
\hline Dickeya zeae & Fungus \\
\hline Diplodia sp. & Fungus \\
\hline Diplodia orticola & Fungus \\
\hline Diplodia serata & Fungus \\
\hline Erwinia sp. & Fungus \\
\hline Fusarium sp. & Fungus \\
\hline Macrophomina parvum & Fungus \\
\hline Macrophominaphaseolina & Fungus \\
\hline Neofusicoccum parvum & Fungus \\
\hline Pseudomonas fluorenscens & Bacteria \\
\hline Pseudomonas libanensis & Bacteria \\
\hline Pseudomonas aeruginosa & Bacteria \\
\hline Pseudomonas tolaasii & Bacteria \\
\hline Penicillium brasiliarum & Fungus \\
\hline Penicillium chrysogenum & Fungus \\
\hline Penicillium decumbens & Fungus \\
\hline Penicillium digitatum & Fungus \\
\hline Penicillium expansum & Fungus \\
\hline Penicillium marneffei & Fungus \\
\hline Penicillium steckii & Fungus \\
\hline Pestalotiopsis sp. & Fungus \\
\hline Pestalotiopsisfici & Fungus \\
\hline Pseudomonas aeroginosa & Bacteria \\
\hline Pseudomonas brassicacearum & Bacteria \\
\hline Pseudomonas dioxanivorans & Bacteria \\
\hline Pseudomonas fluorecens & Bacteria \\
\hline Pseudomonas fuscovaginae & Bacteria \\
\hline Pseudomonas mendocina & Bacteria \\
\hline Pseudomonas pseudoalcaligenes & Bacteria \\
\hline Pseudomonas syringae & Bacteria \\
\hline Pseudomonas tolaasii & Bacteria \\
\hline Pseudoxanthomonas sp. & Bacteria \\
\hline Pseudoxanthomonas spadix & Bacteria \\
\hline Sordariomycetidae & Bacteria \\
\hline Xanthomonas sp. & Bacteria \\
\hline Xanthomonas citri & Bacteria \\
\hline Xanthomonas euvesicatoria & Bacteria \\
\hline Xanthomonas phaseoli & Bacteria \\
\hline Xanthomonas sacchari & Bacteria \\
\hline
\end{tabular}


Table 3. Plant pathogenic microorganisms among list of bacteria and fungi identified through NGS—according to literature review

\begin{tabular}{l}
\hline Microorganisms \\
\hline Diplodiaseriata \\
Diplodiacorticola \\
Macrophominaphaseolina \\
Neofusicoccum parvum \\
Diaporthehelianthi \\
Diaportheampelina \\
Pestalotiopsis \\
\hline
\end{tabular}

Neofusicoccum parvum is the predominant species within the Botryosphaeriaceae. Several Botryosphaeriacea species are important grapevine pathogens causing dieback and decline worldwide, and in recent years they have been recognized as causing serious problems in New Zealand vineyards (Baskarathevan et al., 2012).

Diplodia corticola A.J.L. Philips, Alves et Luque is a well-known canker pathogen of oak (Quercus spp.) that is contributing to the decline of oaks in the Mediterranean region (Alves et al., 2004). Recently, the pathogen has been affecting Quercus spp. in California, Vitis vinifera in California and Texas (Lynch et al., 2010; Úrbez-Torres et al., 2009; Úrbez-Torres et al., 2010), and live oak (Q. virginiana Mill.) in Florida (Dreaden et al., 2011).

Diplodia seriata (= Botryosphaeriaceaeobtusa) and Neofusicoccum parvum (Pennycook \& Samuels) Crous, are the most common pathogens associated with grapevine dieback worldwide (Auger et al., 2004; Larignon et al., 2001; Phillips, 2002, Taylor et al., 2005; Úrbez-Torres et al., 2006; Úrbez-Torres et al., 2006; Van Niekerk et al., 2004).

Species of Diaporthe and their Phomopsis asexual states have broad host ranges and are widely distributed, occurring as plant pathogens, endophytes or saprobes, but also as pathogens of humans and other mammals (Webber \& Gibbs, 1984; Carroll, 1986; Boddy \& Griffith, 1989; Rehner \& Uecker, 1994; Garcia-Reyne et al., 2011; Udayanga et al., 2011).

Diaporthe sp. are responsible for diseases on a wide range of plants hosts, some of which are economically important worldwide, causing root and fruit rots, dieback, cankers, leaf spots, blights, decay and wilt (Uecker, 1988; Mostert et al., 2001a; van Rensburg et al., 2006; Santos et al., 2011; Thompson et al., 2011).

More researches are currently ongoing and each suspected microorganisms above needs to be confirmed by the Koch Postulates assays as causative pathogen(s) of CRND in western DRC.

Isolations of bacteria and fungi are currently ongoing with the partnership of the Plant Clinic of Kinshasa. Microorganisms that will be isolated from cassava roots necrotic tissues will be genetically characterized and sequenced.

Koch Postulates trials will be done with the involvement of the DSMZ (Deutsche Sammlung von Mikroorganismen und Zellkulturen) in Germany.

It is possible that the CRND root necrosis disease could be caused by the action of a bacterium-fungus complex.

The disease could be initiated by an initial attack of bacteria and root necrotic symptoms externalized by a secondary attack of fungi. Further studies are required to confirm or refute this hypothesis.

\section{Conclusion and Perspectives}

This study points to the apparent absence of CBSV in western region of DRC and suggests that CRND could be caused by other microorganisms such as bacteria, fungi or a combination of both. There appear to be two distinct diseases, namely CRND and CBSD which have similar root symptoms but different stem and foliar symptoms.

Since 2004, CBSD has been spreading from East Africa to Central Africa and was confirmed in 2012 in eastern DRC; it is expected to spread to western DRC and on to West Africa. At the same time, CRND is spreading from western DRC towards West Africa and eastern DRC.

If no control measures (quarantine, etc.) are put in place, there is a strong possibility that both diseases will spread to West Africa. Should this event cause cases of infections of both diseases, the results are likely to mean devastating cassava root crop losses and significant economic impacts on farmers' livelihoods. Ultimately, this has serious implications for food security in Central Africa. 
We consider that further research on CRND pathogens identification is paramount. Koch's Postulates on isolated microorganisms from diseased plants and other biological assays will help to elucidate the causal pathogens of this disease. Information on disease etiology will allow for future disease epidemiology and genetic disease resistance research.

\section{Acknowledgements}

We would like to thank the WAVE program and BMGF (Grant number OPP1082413) for funding this study.

We would also like to thank the farmers of the Lukuakua village for providing us with cassava samples which were sent to Australia for analysis.

\section{References}

Adams, I. P., Glover, R. H., Monger, W. A., Mumford, R., Jackeviciene, E., Navalinskiene, M., ... Boonham, N. (2009). Next-generation sequencing and metagenomic analysis: An universal diagnostic tool in plant virology. Mol. Plant Pathol., 10(4), 537-45. https://doi.org/10.1111/j.1364-3703.2009.00545.x

Alicai, T., Omongo, C. A., Maruthi, M. N., Hillocks, R. J., Baguma, Y., Kawuki, R., ... Colvin, J. (2007). Re-emergence of cassava brown streak disease in Uganda. Plant Dis., 91, 24-29. https://doi.org/ 10.1094/PD-91-0024

Alicai, T., Ndunguru, J., Sseruwagi, P., Tairo, F., Okao-Okuja, G., Nanvubya, R., ... Boykin, L. M. (2016). Cassava brown streak virus has a rapidly evolving genome: implications for virus speciation, variability, diagnosis and host resistance. Scientific Resports, 6, 36164. https://doi.org/10.1038/srep36164

Altschul, S. F, Gish, W., Miller, W., Myers, E. W., \& Lipman, D. J. (1990). Basic local alignment search tool. J. Mol. Biol., 215(3), 403-10. https://doi.org/10.1016/S0022-2836(05)80360-2

Ateka, E., Alicai, T., Ndunguru, J., Tairo, F., Sseruwagi, P., Kiarie, S., ... Boykin, L. M. (2017). Unusual occurrence of a DAG motif in the Ipomovirus Cassava brown streak virus and implications for its vector transmission. PLoS ONE, 12(11). https://doi.org/10.1371/journal.pone.0187883

Auger, J., Esterio, M., Ricke, G., \& Perez, I. (2004). Black dead arm and basal canker of Vitis vinifera cv. Red globe caused by Botryosphaeriaobtusa in Chile. Plant Dis., 88, 1286. https://doi.org/10.1094/PDIS. 2004.88.11.1286A

Baskarathevan, J., Jaspers, M. V., Jones, E. E., Cruickshank, R. H., Ridgway, H. J., \& Spatafora, J. W. (2011). Genetic and pathogenic diversity of Neofusicoccum parvum in New Zealand vineyards. Fungal Biology, 116(2), 276-288. https://doi.org/10.1016/j.funbio.2011.11.010

Bakelana, Z., Musben, Z., Boykin, L., Pita, J., Mvila, A., Monde, G., ... Tshilenge, K. (2018). First Report and Preliminary Evaluations of Cassava Brown Streak-Like Root Necrosis in Congo Republic. International Journal of Development Research, 8(08), 22400-22407.

Bakelana, Z., Magembe, E., Boykin, L., Macharia, M., Mahungu, N., Tata, H., ... Tshilenge, K. (2019a). Attempts to Identify Cassava Brown Streak Virus in Western Democratic Republic of Congo. Journal of Agricultural Science, 11(2), 31. https://doi.org/10.5539/jas.v11n2p31

Bakelana, Z., Boykin, L., Mahungu, N. M., Mavila, N., Matondo, M., Lufuankenda, M., ... Tshilenga, K. (2019b). First report and preliminary evaluation of cassava root necrosis in angola. International Journal of Agriculture, Environment and Bioresearch, 4(03), 37-46. https://doi.org/10.35410/IJAEB.2019.3746

Bigirimana, S., Barumbanze, P., Ndayihanzamaso, P., Shirimana, R., \& Legg, J. P. (2011). First report of Cassava brown disease and associated Ugandan cassava brown streak virus in Burundi. New Dis. Rep., 24(26). https://doi.org/10.5197/j.2044-0588.2011.024.026

Chalupowicz, L., Dombrovsky, A., Gaba, V., Luria, N., Reuven, M., Beerman, A., ... Manulis-Sasson, S. (2019). Diagnosis of plant diseases using the Nanopore sequencing platform. Plant Pathol., 68, 229-238. https://doi.org/10.1111/ppa.12957

Dreaden, T. J., Shin, K., \& Smith, J. A. (2011). First report of Diplodia corticola causing branch cankers on live oak (Quercus virginiana) in Florida. Plant Dis. 95:1027.corticola causing grapevine (Vitis vinifera) cankers and trunk cankers and dieback of canyon live oak (Quercus chrysolepis) in California. Plant Dis., 94, 785. https://doi.org/10.1094/PDIS-02-11-0123

Dombrovsky, A., Reingold, V., \& Antignus, Y. (2014). Ipomovirus-An atypical genus in the family Potyviridae transmitted by whiteflies. Pest Manag Sci., 70(10), 1553-67. https://doi.org/10.1002/ps.3735 
Drummond, A. J., Ashton, B., Buxton, S., Cheung, M., Cooper, A., \& Heled, J. (2010). Geneious v5.1. Retrieved from http://www.geneious.com

Dufour, D., O’Brien, G. M., \& Rupert, B. (1996). Cassava flour and starch: Progress in research and development. CIAT.

FAO (Food and Agriculture Organization). (2011). Cassava Virus on Verge of Epidemic in East Africa: Expert Urge funding, Swift Action to Protect Staple Food Crop. Rome: Food and Agricultural Organization.

FAO (Food and Agriculture Organization). (2013). Save and Grow Cassava: A Guide to Sustainable Production Intensification. Rome: Food and Agriculture Organizationof the United Nations.

Garcia, B. J., Labbé, J. L., Jones, P., Abraham, P. E., Hodge, I., Climer, S., \& Jacobson, D. A. (2018). Phytobiome and Transcriptional Adaptation of Populus deltoides to Acute Progressive Drought and Cyclic Drought. Phytobiomes Journal, 2(4), 249-260. https://doi.org/10.1094/pbiomes-04-18-0021-r

Hillocks, R. J., \& Thresh, J. M. (2002). Cassava Biology, Production and Utilization. Wallingford, CT: CABI. https://doi.org/10.1079/9780851995243.0000

IITA (International Institute of Tropical Agriculture). (2014b). IITA-led SCP project reports great strides in regional exchange of improved cassava varieties. IITA News, Ibadan.

Jarvis, A., Ramirez-Villegas, J., Herrera Campo, B. V., \& Navarro-Racines, C. (2012). Is cassava the answer to African climate change adaptation? Trop. Plant Biol., 5, 9-29. https://doi.org/10.1007/s12042-012-9096-7

Kreuze, J. F., Perez, A., Untiveros, M., Quispe, D., Fuentes, S., Barker, I., \& Simon, R. (2009). Complete viral genome sequence and discovery of novel viruses by deep sequencing of small RNAs: A generic method for diagnosis, discovery and sequencing of viruses. Virology, 388(1), 1-7. https://doi.org/10.1016/j.virol. 2009.03.024

Larignon, P., Fulchic, R., Cere, L., \& Dubos, B. (2001). Observations of Black dead arm in French vineyards. Phytophathol. Mediterr., 40, 336-342.

Le May, C., Potage, G., Andrivon, D., Tivoli, B., \& Outreman, Y. (2009). Plant disease complex: Antagonism and synergism between pathogens of the ascochyta blight complex on pea. Journal of Phytopathology, 157(11-12), 715-721. https://doi.org/10.1111/j.1439-0434.2009.01546.x

Lynch, S. C., Eskalen, A., Zambino, P. J., \& Scott, T. (2010). First report of Bot canker disease caused by Diplodia corticola on coast live oak (Quercus agrifolia) in California. Plant Dis., 94, 1510. https://doi.org/10.1094/PDIS-04-10-0266

Mahungu, N. M, Bidiaka, M., Tata, H., Lukombo, S., \& N'luta, S. (2003). Cassava brown streak disease-like symptoms in Democratic Republic of Congo. ROOTS, 8, 8-9.

Markowitz, V. M., Chen, I. M. A., Palaniappan, K., Chu, K., Szeto, E., Grechkin, Y., ... Kyrpides, N. (2012). IMG: The integrated microbial genomes database and comparative analysis system. Nucleic Acids Res., 40, D115-D122. https://doi.org/10.1093/nar/gkr1044

Masumba, E. A., Kapinga, F., Mkamilo, G., Salum, K., Kulembeka, H., Rounsley, S., ... Ferguson, M. (2017). QTL associated with resistance to cassava brown streak and cassava mosaic diseases in a bi-parental cross of two Tanzanian farmer varieties, Namikonga and Albert. Theor Appl Genet, 130, 2069-2090. https://doi.org/10.1007/s00122-017-2943-z

Mbago, B. S., \& Lotombe, B. G. (2017). Democratic Republic of Congo: Improving cassava production and supply systems. SNV Netherlands Development Organisation.

Mbanzibwa, D. R., Tian, Y. P., Mukasa, S. B., \& Valkonen, J. P. (2009). Cassava brown streak virus (Potyviridae) encodes a putative Maf/HAM1 pyrophosphatase implicated in reduction of mutations and a P1 proteinase that suppresses RNA silencing but contains no HC-Pro. Journal of Virology, 83, 6934-6940. https://doi.org/ 10.1128/JVI.00537-09

Mbanzibwa, D. R., Tian, Y. P., Tugume, A. K., Patil, B. L., Yadav, J. S., Bagewadi, B., ... Valkonen, J. P. (2011). Evolution of cassava brown streak disease-associated viruses. J. Gen. Virol., 92(4), 974-87. https://doi.org/ 10.1099/vir.0.026922-0

Menzel, P., Ng, K. L., \& Krogh, A. (2016). Fast and sensitive taxonomic classification for metagenomics with Kaiju. Nature Communications, 7, 1-9. https://doi.org/10.1038/ncomms11257

Mohammed, I. U., Abarshi, M. M., Muli, B., Hillocks, R. J., \& Maruthi, M. N. (2012). The symptom and genetic 
diversity of cassava brown streak viruses infecting cassava in East Africa. Adv Virol., 2012, 795697. https://doi.org/10.1155/2012/795697

Monger, W. A., Seal, S., Isaac, A. M., \& Foster, G. D. (2001a). Molecular characterisation of Cassava brown streak virus coat protein. Plant Pathology, 50, 527-534. https://doi.org/10.1046/j.1365-3059.2001.00589.x

Monger, W., Alicai, T., Ndunguru, J., Kinyua, Z. M., Potts, M., Reeder, R. H., ... Smith, J. (2010). The complete genome sequence of the Tanzanian strain of Cassava brown streak virus and comparison with the Ugandan strain sequence. Archives of Virology, 155(3), 429-433. https://doi.org/10.1007/s00705-009-0581-8

Monger, W. A., Alicai, T., Ndunguru, J., Kinya, Z. M., Potts, M., Reeder, R. H., ... Smith, J. (2010). The complete genome sequence of the Tanzanian strain of Cassava brown streak virus and comparison with the Ugandan strain sequence. Arch. Virol., 155, 429-33. https://doi.org/10.1007/s00705-009-0581-8

Mulimbi, W., Phemba, X., Assumani, B., Kasereka, P., Muyisa, S., Ugentho, H., ... Thom, F. E. F. (2012). First report of Ugandan cassava brown streak virus on cassava in Democratic Republic of Congo. New Dis. Rep., 26(11). https://doi.org/10.5197/j.2044-0588.2012.026.011

Mware, B., Narla, R., Amata, R., Olubayo, F., Songa, J., Kyamanywa, S., \& Ateka, E. M. (2009). Efficiency of Cassava brown streak virus transmission by two whitefly species in coastal Kenya. J. Gen. Mol. Virol., 1, 40-5.

Ndunguru, J., Sseruwagi, P., Tairo, F., Stomeo, F., Maina, S., Djinkeng, A., ... Boykin, L. M. (2015). Analyses of Twelve New Whole Genome Sequences of Cassava Brown Streak Viruses and Ugandan Cassava Brown Streak Viruses from East Africa: Diversity, Supercomputing and Evidence for Further Speciation. PLoS ONE, 10(10), e0139321. https://doi.org/10.1371/journal.pone.0139321

Nweke, F. (2014). New challenges in the cassava transformation in Nigeria and Ghana. Int. Food Pol. Res. Inst, . 118 .

Ogwok, E., Alicai, T., Rey, M. E. C., Beyene, G., \& Taylor, N. J. (2015). Distribution and accumulation of cassava brown streak viruses within infected cassava (Manihot esculenta) plants. Plant Pathol., 64(5), 1235-1246. https://doi.org/10.1111/ppa.12343

O’Leary, N. A., Wright, M. W., Brister, J. R., Ciufo, S., Haddad, D., McVeigh, R., \& Pruitt, K. D. (2016). Reference sequence (RefSeq) database at NCBI: Current status, taxonomic expansion, and functional annotation. Nucleic Acids Research, 44(D1), D733-D745. https://doi.org/10.1093/nar/gkv1189

Patil, B. L., Ogwok, E., Wagaba, H., Mohammed, I. U., Yadav, J. S., Bagewadi, B., ... Fauquet, C. M. (2011). RNAi-mediated resistance to diverse isolates belonging to two virus species involved in Cassava brown streak disease. Mol. Plant Pathol., 12(1), 31-41. https://doi.org/10.1111/j.1364-3703.2010.00650.x

Patil, B. L., Legg, J. P., Kanju, E., \& Fauquet, C. M. (2015). Cassava brown streak disease: a threat to food security in Africa. J. Gen. Virol., 96, 956-968. https://doi.org/10.1099/vir.0.000014

Roux-Cuvelier, M., Teyssedre, D., Chesneau, T., Jeffray, C., Massé, D., Jade, K., ... Lett, J. M. (2014). First report of Cassava brown streak disease and associated Ugandan cassava brown streak virus in Mayotte Island. New Dis. Rep., 30(28). https://doi.org/10.5197/j.2044-0588.2014.030.028

Rwegasira, G. M., Rey, M. E. C., \& Nawabu, H. (2011). Approaches to diagnosis and detection of cassava brown streak virus (Potiviridae: Ipomovirus) in field-grown cassava crop. African Journal of Food, Agriculture, Nutrition and Development, 11(3). https://doi.org/10.4314/ajfand.v11i3.66626

Salzberg, S. L., \& Wood, D. E. (2014). Kraken: Ultrafast metagenomic sequence classification using exact alignments. Genome Biology, 15. https://doi.org/10.1126/science.1093857

Taylor, A., Hardy, G. E. St. J., Wood, P., \& Burgess, T. (2005). Identification and pathogenicity of Botryosphaeria species associated with grapevine decline in Western Australia. Aust. Plant Pathol., 34, 187-195. https://doi.org/10.1071/AP05018

Úrbez-Torres, J. R., Leavitt, G. M., Voegel, T., \& Gubler W. D. (2006). Identification and distribution of Botryosphaeria species associated with grapevines cankers in California. Plant Dis., 90, 1490-1503. https://doi.org/10.1094/PD-90-1490

Úrbez-Torres, J. R., Adams, P., Kamas, J., \& Gubler, W. D. (2009). Identification, incidence, and pathogenicity of fungal species associated with grapevine dieback in Texas. Am. J. Enol. Vitic., 60, 497-507.

Van Niekerk, J. M., Crous, P. W., Groenewald, J. Z., Fourie, P. H., \& Halleen, F. (2004). DNA phylogeny, 
morphology and pathogenicity of Botryosphaeria species on grapevines. Mycologia, 96, 781-798. https://doi.org/10.1080/15572536.2005.11832926

Winter, S., Koerbler, M., Stein, B., Pietruszka, A., Paape, M., \& Butgereitt, A. (2010). Analysis of cassava brown streak viruses reveals the presence of distinct virus species causing cassava brown streak disease in East Africa. J. Gen. Virol., 91(5), 1365-72. https://doi.org/10.1099/vir.0.014688-0

\section{Copyrights}

Copyright for this article is retained by the author(s), with first publication rights granted to the journal.

This is an open-access article distributed under the terms and conditions of the Creative Commons Attribution license (http://creativecommons.org/licenses/by/4.0/). 